\title{
School Readiness of Preschool Children Entering Elementary School Based on Nijmeegse Schoolbekwaamheids Test (Nst) (Case Study at Early Childhood Education Al Husna Pengging Boyolali In 2017) \\ Nur Fauziyah, S.Psi, Psikolog, M.Pd ${ }^{1}$ \\ ${ }^{1}$ Muhammadiyah University of Surakarta
}

\section{ABSTRACT}

This is descriptive research to find out school readiness in terms of N.S.T (Nijmeegse Schoolbekwaamheids Test) test results. Research uses quantitative approach. Subject of the research is students of early childhood education Al Husna Kindergarten B level in Pengging Boyolali which will enter elementary school. Number of research subject is 32 students. Measuring instrument used on the research is N.S.T (Nijmeegse Schoolbekwaamheids Test) and also observation. Analysis of data will be done quantitatively with simple statistic technique. Result of the research shows that from 32 students, 50\% stated has readiness as much 16 students, $40,6 \%$ is quite ready as much 13 students meanwhile not ready is $9,4 \%$ as much 3 students.

The most prominent aspect in its level of maturity is aspect of form observations and the ability to distinguish which is $84,4 \%$ for 27 students. The least aspect on the task of understanding the story is $25 \%$ for 8 students. Qualitatively, school readiness aspect from cognitive aspect is observation and the ability to distinguish, notions of big, number and comparison, concentrate and memory already reaches a fairly optimal level of maturity. Meanwhile related aspect with understanding stories and pictures of people skill the level of preparedness is not yet optimal.

\section{KEY WORDS}

school readiness, nst test, preschool children

CORRESPONDING AUTHOR:

email: nf122@ums.ac.id

Manuscript submitted October 21, 2019; accepted December 7, 2019.

Copyright: @2019 This is an open access article under the terms of the Creative Commons Attribution License, which permits unrestricted use, distribution, and reproduction in any medium, provided the original author and source are credited.
ECRJ (Early Chilhood Research Journal)

ISSN Numbers: Print, 2655-6448; Online, 2655-9315

ADDRESS

Website: http://journals.ums.ac.id/index.php/ecrj

Address: Pendidikan Guru PAUD

Universitas Muhammadiyah Surakarta

A. Yani Street No. 1, Pabelan, Kartasura, Surakarta, Indonesia

Telp. +62-271-717417 ext.

Email:ecrj@ums.ac.id

\section{INTRODUCTION}

Requirements for a child to be accepted in Elementary School are different when the children are still in the kindergarten. Children are required to be independent, discipline, responsible for tasks given by teacher and must fulfill academic basic education demands in the elementary school. This education is a beginning because instruct a child to read well, sharpen the ability to count and think. Therefore children readiness for school has the important role because this will influence profits and progress in the next development. 
The result of the research by Clarke-Stewart and Fein (Santrock, 2010), early childhood has been following education program (Playgroup or Kindergarten), they are more independent, competent and mature socially, means they are more confident, can express verbally itself, understand social world, can adjust itself into pleasant social condition also unpleasant condition (Damayanti, 2014). We frequently hear children which will enter elementary school given several entrance tests. We perhaps hear parents will think to prepare children ability optimally. Especially children are capable in writing, reading letter and if necessary able to count. In consequent, school readiness test seems requires do, usually when children will enter elementary school required to handle learning situation in class 1 . Even though, this test looks alike with intelligent test emphasizing ability considered important to study reading, mathematical thinking requirements and sensory motor required to study writing.

School readiness between one to another children are not same, even when they are at the same age. Children who have readiness for school will get benefit and progress in the next development. Meanwhile children which are not having forwardness, it will be frustrated if placed in an academic location. Several behavioral standards as reflection of this frustration such as withdrawn, indifferent, showing physical symptoms or struggle finishing his task in school (Sulistiyaningsih 2005). Apart from being influenced by maturity, the environment in which the child develops also create school readiness child. There are several environment factors which relevant to discuss related to readiness school case is school and family (Halimah dan Fajar, 2010).

Readiness school on field in reality involves physical readiness, cognitive, emotion and social become things that are not noticed, the reality is not a bit elementary schools who accept students by doing reading, writing and counting test can be said, it is not proper to score school readiness for children. This is also in line with parents opinions which assess success in kindergarten is preparing children capable to read, write and count before entering elementary school.

\section{School Readiness}

a. Definition of School Readiness

School readiness according to Narendra (2007) is child development milestones on early childhood stage where children is ready to follow transition activity from home to school involves 5 competency aspects, physical health and motoric development, emotional health and positive approach toward new experience, knowledge and social competency, language skills and general knowledge skills and cognitive.

Pat Nuse Pratt and Anne Stevens (Kustimah, 2008) stated child's readiness more detail, which are able to fulfill school demand, a child must have several readiness academic skill as basic for learning numeracy skill, write and read. School readiness academic which means include motoric skill, language skill, visual perception skill, cognitive skill and also emotional and social skills. 
Britto (2012) school readiness includes child's readiness (focused on learning and children development), school readiness (focused on supporting facilities and infrastructure smooth transition learning process children to elementary school) and the last is family readiness (focused on parent's attitude and caregiver in his involvement in preparing transition stage to school). These three dimensions are interrelated and cannot be separated.

In conclusion, school readiness is child's readiness involves physical readiness, mental, social, emotional and intelligence, school readiness in children learning process and also family readiness which interrelated.

\section{b. School Readiness Factor}

Important development factor in supporting the readiness of children entering school according to Kustimah (2008) is:

1) Physical Health

Good health with a balanced nutritional intake is very required to able support to enter school readiness. Healthy children will easier digest the knowledge being taught also better socialize, appear nimble and vibrant, both in accepting information and in fostering social relations with teacher and their friends.

2) Age

Several experts said that age factor is very important to determine the readiness of children entering elementary school. According to
Comenius, Buhler and Hetzer in Nijmeegse Schoolbekwaamheids Test book (in Kustimah, 2008) considered 6 years old as quite mature age to school. In this age, children generally has quite a lot vocabularies, having ability to imagine like kids his age, can deliver ideas and thoughts verbally also sense organs and motoric have coordinated well.

3) Level of Intelligence

Intelligence is children ability in understanding verbal theoretic instruction and finishing concrete practical tasks compare with children on their age. Children with level of intelligence which function on average level will finish those tasks as fast as children on their age. There are children who have high level of intelligence will finish the tasks faster and the opposite the children who have lover level of intelligence will finish it slower. Hereby for entering school world which has learning program for certain ages, at least a child has level of intelligent which functions at an average stage.

4) Precise Stimulation

Surround closest environment factor with children have important role in supporting children readiness entering elementary school, so that development potential on children which they have will grow optimally. Parents and teachers hold important role in developing aspects which very support children readiness for school involve every development from gross and fine motor development, language development, 
social development, cognition development and children emotional development.

5) Motivation

Children who feel happy usually have well motivation to do, generally doing activity is based on certain purpose.

Nijmeegse Schoolbekwaamheids Test (N.S.T.) arranged by Prof. F.J. Mönks, Drs. H. Rost and Drs. N.H. Coffie (2011) is measurement device to know aspects maturity which support children readiness entering elementary school. This test consists of $10 \mathrm{sub}$ test, with test description contained pictures or complete the picture at once with the answers, which each aspects reveal different ability, there are: 1 . Sub test 1 : form observation and ability to distinguish (vorm waarneming en onderscheidings vermogen); 2 . Sub test 2 : Fine Motor (fijne motoriek); 3 . Subtest 3: Notions of large, number and comparison (begrip voor grootte hoeveelheid en verhoudingen); 4 . Sub test 4: Sharpen observation (scherp waarnemen); 5. Sub test 5: Critical thinking ability (kritische waarneming); 6. Concentration (taakspanning); 7. Sub test 7: Memory (geheugen); 8. Sub test 8: Definition of object and situational assessment (object begrip en situatieboordeling); 9 . Sub test 9: Imitate the story (weergeven van een verhaaltje); 10.Subtes 10: Describing people (menstekening). According to Monks, Rost, dan Coffie (2011) NST developed in Nijmegen Nederland is Gopinger test processing from Germany used to reveal children school ability. Similar things are expressed that NST is a test device used to reveal readiness to enter elementary school, including physical readiness and psychic readiness. Psychic readiness consists of emotional mature, social and intellectual. NST is non-verbal and presented individually.

It can concluded that children school readiness consists of several aspects, physic or psychology and one of the test device to measure school readiness is Nijmeegse Schoolbekwaamheids Test (NST) which measure cognitive aspects, fine and rough motor, social assessment and also emotional.

\section{RESEARCH METHOD}

\section{Type and Research Method}

Type of the research is quantitative research with survey method. Analysis of the data will be done quantitative with statistic simple technique.

\section{Research Site}

Research site is in Al Husna Early Childhood Education Pengging Boyolali. Implementation time is on 15-16 October 2017.

\section{Research Subject}

Research subject is students at B1 and B2 level of kindergarten as many as 32 students.

\section{Method of Collecting Data}

Method of collection data in this research is test method and also observation. The result of the test is using NST as its instrument. NST is used to see readiness entering elementary school which consists of 10 sub test and 8 test every sub test. NST is established three standards, for the results which are adolescent, 
doubt and mature. Moreover, it is used observation method. Meanwhile for observation is done to observe independently and also self-adjustment by using observation guide or table of contents that contains a series of attitudes show those aspects.

\section{Technique of Data Analysis}

Analysis technique in this research is descriptive statistic used, like: 1) Data presentation is in the form of table or frequency distribution and cross tabulation. It will be known tendency of research finding in this analysis, whether entering in low category, middle or high; 2) Data presentation is in the form of visual like histogram, polygon, ogive, bar chart, pie chart, pastel diagram and symbol diagram; 3) Calculation of the size of center tendencies (mean, median and modus); 4) Location size calculation (quartile, decile, presentile); 5) deployment size calculation (standard deviation, variance, range, quartile deviation, mean deviation and many more) (Sudjana 1994, 30).

\section{Result of Data Analysis}

Result of data analysis used in this research is statistic descriptive analysis, which is statistic used in analysing data by describing collected data (Suryabrata, 1994). Analysis result will be obtained is descriptive description about children readiness entering elementary school in term of N.S.T (Nijmeegse Schoolbekwaamheids Test) test result consist of general description of readiness study aspects, which are observation and ability to distinguish, fine motor, notions of big, amount and comparison, sharpness of observation, critical observation, concentration, memory, notion of objects and assessment toward situation and understanding story and picture of people.

\section{RESULT AND DISCUSSION \\ Discussion}

After doing assessment about school readiness test by using NST (Nijmeegse Schoolbekwaamheids Test) obtained results are as follows: on examination of 32 students of B level in Kindergarten. Obtained result that on 16 students have readiness to follow learning process in elementary school, 13 students quite ready and 3 students are not ready to follow learning process in elementary school. The result can be described are as follows, on Image 1. Below this:

Image 1.

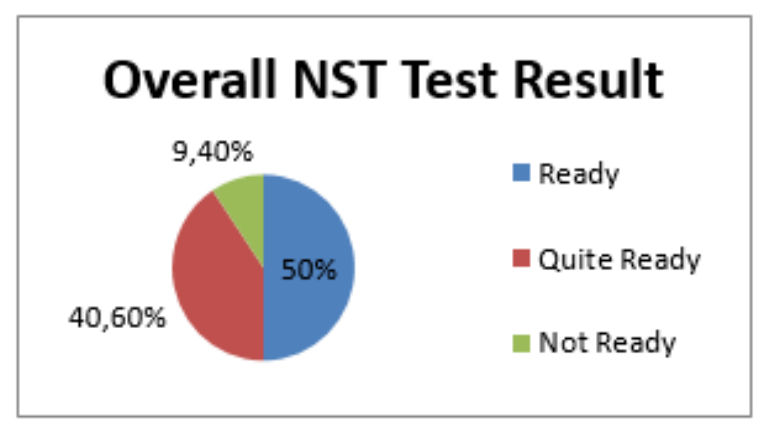

Data acquisition from the test result later entered into excel to process in simple statistic to obtain category and number of children percentage which included in ready category, quite ready, and not ready in every sub test (there are 10 sub tests). The results obtained from every sub test measures in NST presented in Image 2 are as follow: 
From readiness school aspects and the result of the data analysis seem look different. Children school readiness which one child is not necessarily the same as another child, even when they are at the same age. This is caused by many factors which influence children school readiness formed. Besides being influenced by maturity, environment where the children develop are also shaped children school readiness. Children readiness entering elementary school will be different one another. This depends on stimulation given and reached maturity. Maturity achievements that need attention involves children development aspects, physical and motor, social, emotional, and cognitive (Jannah, 2015).

\section{CONCLUSION}

From the research result that has been done in Al Husna Early Childhood Education Pengging Boyolali concluded that from 32 students, $50 \%$ stated have ready for 16 students, $40,6 \%$ is quite ready for 13 students, and not ready is $9,4 \%$ for 3 students.

The most stand out aspect of maturity level is aspects of form observation and ability to distinguish which is $84,4 \%$ for 27 students. The least aspect is on task of understand the story which are $25 \%$ for 8 students. Qualitatively, school readiness aspects form cognitive aspects are observation and ability to distinguish, notion of big, amount and comparison, concentration and memory already reach quite optimal on level of maturity. Whereas related aspect with understand the story and picture of people skill is not quite optimal in the level of maturity.

\section{Suggestions}

Based on the research result then parents and teacher can be suggested to:

1. Giving stimulation on several students development aspects so school readiness can ne optimal, remember the optimal children development can only be achieved when all development aspect is well stimulated including social and emotional aspects.

2. School is capable in facilitating parents in parenting activities for more recognize the needs of growth and development of their children.

3. For the next researcher to do refinement of measuring instruments school readiness which suitable with Indonesian cultural context.

\section{REFERENCES}

Britto, P.R. 2012. School Readiness: a conceptual framework. New York: United Nations Children's Fund (UNICEF).

Damayanti, A.K \& Rachmawati, R. 2016. Kesiapan Anak Masuk Sekolah Dasar ditinjau dari

Dukungan Orangtua dan Motivasi Belajar. Jurnal PSIKOVIDYA. Volume 1- 2016.

Halimah, N., dan Kawuryan, F. 2010. Kesiapan Memasuki Sekolah Dasar Pada Anak yang Mengikuti Pendidikan TK dengan yang Tidak Mengikuti Pendidikan TK di Kabupaten Kudus. Jurnal Psikologi Universitas Muria Kudus.Vol.1.No.1, 1-8.

Kustimah, Kusumawati, D., \& Abidin, F.A. 2008. Gambaran Kesiapan Anak Masuk Sekolah Dasar di Tinjau Dari Hasil Tes N.S.T. Bandung: Jurnal Psikologi Vol. 21. No. 1. 
Jannah, M. (2015). Menakar Kesiapan Anak Masuk Sekolah. [Online]. Tersedia:

http://www.mjariseno.blogspot.com/2015/02/menakarkesiapan-anak-masuk-sekolah.html?m=1. [30 Desember 2018].

Narendra, M.B., \& D, M. 2007. School Readiness (Kesiapan Sekolah). Sari Pediatri Vol.8, No.4 (Suplemen), 85-93.

Santrock, J.W. 2010. Psikologi Pendidikan Edisi 2 . Jakarta:Kencana.

Sudjana. (1994). Metoda Statistika. Bandung: Tarsito

Sulistiyaningsih, W. 2005. Kesiapan Bersekolah Anak Ditinjau Dari Jenis Pendidikan Pra Sekolah Anak dan Tingkat Pendidikan Orangtua. Medan: Jurnal Psikologia Vol. I. No.1.

Suryabrata, S. (1994). Metodologi Penelitian. Jakarta: Raja Garafindo Persada. 